\title{
The Dynamics of International Norms Diffusion: The Study of Women Activists in Bali
}

\author{
Dinamika Difusi Norma Internasional: \\ Studi tentang Aktivis Perempuan di Bali
}

\author{
I Made Anom Wiranata \\ Universitas Udayana
}

\begin{abstract}
ABSTRAK
Artikel ini bertujuan untuk menganalisis pendekatan aktivis-aktivis perempuan di Bali dalam mendifusikan norma global kesetaraan gender. Aktivitas mereka berhadapan dengan adat budaya Bali yang patriarki. Dengan menggunakan metode kualitatifberjenis fenomenologi, penelitian menggambarkan pengalaman aktivis perempuan di Bali dalam ruang transnasionalisme. Penelitian ini menemukan bahwa upaya untuk mendifusikan norma dari ranah globalke ranah domestik dan lokal, tidakterjadi secara linear. Ratifikasi Konvensi mengenai Penghapusan segala Bentuk Diskriminasi terhadap Perempuan oleh Pemerintah Indonesia pada tahun 1984, tidak berarti bahwa norma kesetaraan gender dapat menyebar dan terinternalisasi dalam masyarakat secara otomatis. Aktivis dalam gerakan perempuan memiliki peran yang penting dalam mempromosikan pentingnya hak-hak perempuan. Mereka melakukan adaptasi agar norma kesetaraan gender pada level global, mendapatkan penerimaan di segmen tertentu dari budaya Bali. Pilihan strategi dalam difusi norma oleh para aktivis perempuan di Bali adalah hasil interaksi antara identitas pemahaman mereka terhadap budaya lokal, interaksi dalam jaringan advokasi internasional serta penggunaan kesempatan politik baik yang berasal dari ranah internasional maupun domestik. Pengalaman berinteraksi langsung dengan aktivis gender di negara Barat menimbulkan gagasan kreatif untuk mengadopsi praktik perjuangan gender yang telah berhasil di luar negeri untuk diterapkan di level lokal.
\end{abstract}

Kata-kata kunci: norma global, difusi, glokalisasi, gerakan gender, transnasionalisme

This article aims to analyze the approach of women activists in Bali in diffusing global norms of gender equality. Their activities deal with patriarchal Balinese cultural tradition. Using a qualitative method of phenomenology, the study describes the experiences of women activists in Bali in the space of transnationalism. This study finds that efforts to diffuse norms from the global to the domestic and local domains do not occur in a linear fashion. Ratification of the Convention on the Elimination of All Forms of Discrimination against Women by the Government of Indonesia in 1984 does not mean that gender equality norms can spread and be internalized in society automatically. Activists in the women's movement have an important role in promoting the importance of women's rights. They make adaptations so that the norms of gender equality at the global level gain acceptance in certain segments of Balinese culture. The strategy choices in the diffusion of norms by women activists in Bali are the result of the interaction between their identity and understanding of local culture, interaction in international advocacy networks and the use of political opportunities both from the international and domestic spheres. The experiences of interacting directly with gender activists in Western countries give rise to creative ideas to adopt the practice of gender movement that has been successful abroad to be applied at the local level.

Keywords: global norms, diffusion, glocalization, gender movement, transnationalism 
The Dynamics of International Norms Diffusion:

The Study of Women Activists in Bali

Model siklus kehidupan norma dari Finnemore dan Sikkink telah menjadi referensi yang tidak pernah ditinggalkan dalam kajian-kajian tentang difusi atau persebaran dalam karya teoritis maupun empiris (Bloomfield 2016; Wylie 2016; Davies et al. 2015; Jose 2016; Iommi 2020). Finnemore dan Sikkink (1998) adalah pakar konstruktivis dalam Hubungan Internasional yang menyatakan bahwa difusi norma terjadi melalui tiga tahap yang disebut sebagai "siklus kehidupan-norma" yaitu norm emergence, norm cascading, dan internalization.

Tahap pertama adalah norm emergence yaitu tahap kemunculan norma internasional, yang ditandai oleh adanya persuasi oleh "entrepreneur" norma. "Entreprenur" norma yang biasanya adalah aktivis internasional, berusaha meyakinkan sejumlah negara untuk menerima norma baru. Tahap kedua (cascade) lebih diwarnai oleh imitasi dinamis, yang di dalamnya negara pengusung norma mensosialisasikan kepada negara lainnya agar juga menerima norma internasional tersebut. Tahap yang ketiga adalah tahap internalisasi norma, yang di dalamnya norma diterima secara taken for granted dan tidak lagi menjadi bagian dari perdebatan (Finnemore dan Sikkink 1998, 895).

Jika tiga tahap difusi norma ini diterapkan pada hak-hak perempuan, maka tahap kemunculan normanya adalah fase yang disebut dengan dekade perempuan, yang dimulaitahun 1975. Tahap cascading-nya adalah adopsi, tanda tangan, dan pemberlakuan Convention on the Elimination of All Forms of Discrimination Against Women (CEDAW) antara tahun 1979-1981. Dengan kata lain, tahap cascading-nya dapat dilihat pada periode 1979-1995 ketika dilakukan ratifikasi CEDAW oleh banyak negara. Tahap yang ketiga, yaitu internalisasi norma, menyaratkan bahwa norma kesetaraan gender tidak lagi dipertanyakan dan diperdebatkan dalam ruang publik (Swingel 2012, 118).

Sampai dengan tahun 2015, CEDAW telah diratifikasi oleh 189 negara (Congressional Research Service 2015). Indonesia telah meratifikasi CEDAW dalam bentuk UU No. 7 Tahun 1984. Dengan merujuk pada model siklus kehidupan-norma dari Finnemore dan Sikkink, maka tahap internalisasi norma global kesetaraan gender di Indonesia telah dimulai semenjak pemberlakuan undangundang tersebut. Di tingkat lokal, tahap internalisasi norma 
kesetaraan gender, tidak terdifusi secara linear seperti yang digambarkan oleh Finnemore dan Sikkink. Berdasarkan catatan LBH APIK, angka kekerasan terhadap perempuan di Bali pada tahun 2019 mencapai 408 kasus. Jumlah ini meningkat hampir dua kali lipat jika dibandingkan dengan tahun sebelumnya di tahun 2018 (Tribun Bali 2020). Menurut pengurus LBH APIK, angka kekerasan terhadap perempuan di Bali, yang didominasi oleh kasus Kekerasan dalam Rumah Tangga (KDRT), disebabkan oleh struktur norma yang patriarki yang membuat posisi perempuan dalam kondisi rentan (Tribun Bali 2020).

Struktur norma patriarki menempatkan kewajiban domestik perempuan Bali secara lebih kompleks jika dikomparasikan dengan kewajiban perempuan di daerah lain di Indonesia (Suryani 2003, 44). Perempuan Bali yang sudah menikah, seperti perempuan lainnya di Indonesia, memiliki tanggung jawab pada tugas-tugas domestik lainnya. Oleh struktur norma tradisi, perempuan Bali juga diharapkan memikul tanggung jawab untuk menghasilkan nafkah untuk memenuhi kebutuhan keluarganya. Di samping itu, perempuan Bali memiliki tanggung jawab untuk mengurus ritual keagamaan (Suryani 2003).

Dari segi representasi politik, persentase anggota DPR perempuan dari daerah pemilihan (dapil) Bali tidak sebanding dengan persentase DPR perempuan secara nasional. Di pemilu 2019, persentase anggota perempuan dalam DPR RI mencapai jumlah 20,87 persen yang merupakan persentase keterwakilan perempuan yang tertinggi dalam sejarah pemilu di Indonesia (Gerintya 2019). Namun, pada pemilu tersebut, dari sembilan orang anggota DPR RI dari dapil Bali, tidak ada satu orang pun perempuan (Gelgel dan Apriani 2019).

Seperti yang dinyatakan oleh Keohane dan Nye (2000), bahwa norma internasional berfungsi melalui perantara kegiatan dari jaringan aktivis-aktivis yang memperjuangkan norma. Upaya untuk mendifusikan norma internasional khususnya di Bali telah dilakukan terutama oleh aktivis-aktivis dan Lembaga Swadaya Masyarakat (LSM) yang bergerak dalam isu kesetaraan gender. Penelitian-penelitian sebelumnya tentang difusi kesetaraan gender sebagian besar membahas tentang peran dari jaringan advokasi internasional yang melakukan tekanan agar norma 
The Dynamics of International Norms Diffusion:

The Study of Women Activists in Bali

kesetaraan gender diberlakukan (Hughes et al. 2015; Jessica 2020). Peneliti lainnya seperti Sørensen (2018) dan Acosta et al. (2019) menyoroti tentang praktik-praktik informal norma patriarki yang telah menghambat difusi norma hak-hak perempuan, meskipun CEDAW telah diratifikasi dan wacana tentang kesetaraan gender telah hadir. Penelitian-penelitian sebelumnya cenderung melewatkan perhatian pada pendekatan yang dilakukan oleh aktivis-aktivis perempuan dalam menginternalisasikan norma internasional kesetaraan gender pada masyarakat di tingkat akar rumput. Artikel ini membahas tentang pengalaman dan pendekatan aktivis-aktivis perempuan di Bali dalam mendifusikan norma global kesetaraan gender.

Penelitian ini menggunakan metodologi kualitatif dengan genre fenomenologi, yaitu studi tentang esensi dari pengalaman sebagaimana dialami dari sudut pandang orang pertama, orang yang mengalaminya (Smith 2013, 1). Data dikumpulkan melalui wawancara mendalam dengan empat narasumber aktivis perempuan di Bali yang memiliki interaksi dengan jaringan internasional. Narasumber pertama adalah Ibu Budawati, pimpinan Bali Women Crisis Centre. Narasumber kedua adalah Ibu Sri Wigunawati, politisi dari Partai Golkar. Beliau juga merupakan Ketua Kaukus Perempuan Politik Indonesia Provinsi Bali. Narasumber ketiga adalah Ibu Luh Riniti. Beliau adalah mantan komisioner KPU Provinsi Bali, pendiri dan pimpinan LSM Bali Sruti. Narasumber keempat adalah Ibu Anggreni. Beliau merupakan pengurus LBH APIK Bali dan mantan pengacara di LBH Bali yang menginisiasi gerakan perempuan di Bali yang berjejaring dengan gerakan perempuan nasional dan internasional.

\section{Glokalisasi dan Ruang Sosial Transnasional}

Glokalisasi adalah istilah yang tepat untuk mengungkapkan hubungan antara global dan lokal (Robertson 1992 dalam Francois 2015, 61). Dengan kata lain, glokalisasi adalah integrasi antara budaya lokal pada satu sisi dengan praktik dalam proyek dan program yang didasarkan pada bingkai globalisasi (Francois 2015, 62). Glokalisasi berarti sejumlah besar orang di seluruh dunia terpapar budaya lain setiap hari meskipun tanpa melintasi batas 
secara teratur, namun dapat dilakukan dengan hanya melalui berbagai media komunikasi (termasuk siaran satelit, radio, dan bentuk komunikasi lainnya). Selain itu, mereka mungkin bertemu dengan orang-orang dari luar negeri di wilayah mereka sendiri (Roudometof 2005, 121).

Koneksi antara norma global dan dinamika lokal, mengalami fase yang menentukan ketika Pemerintah Indonesia meratifikasi normal global CEDAW pada tahun 1984. Pascaratifikasi tersebut, sejumlah aktivis perempuan mengonsolidasikan diri dengan membentuk organisasi yang memperjuangkan keadilan gender di antaranya seperti Kalyana Mitra (1985), Jurnal Perempuan (1995), dan KAPAL (2000). Gerakan perempuan di Bali adalah bagian dari difusi norma CEDAW. Seperti yang dituturkan oleh Ibu Anggreni, gerakan perempuan di Bali baru dimulai sekitar tahun 2000 yang diawali dengan paparan oleh aktivis perempuan dari Jakarta yang berbicara tentang keadilan gender di hadapan sekelompok aktivis perempuan dari berbagai LSM di Bali.

Gagasan tentang keadilan gender itu diterima baik oleh aktivisaktivis perempuan di Bali. Para aktivis perempuan di Bali menjadi terbuka kesadarannya tentang ketidakadilan yang terjadi pada perempuan. Oleh McAdam (1982, 51), hal itu disebut dengan pembebasan kognisi, yaitu suatu proses yang di dalamnya terdapat anggota-anggota dari kelompok yang tidak puas, menciptakan kombinasi yang spesifik tentang pemahaman bersama yang menjadi dasar dari tindakan kolektif. Gerakan perempuan di Bali membesar secara signifikan ketika ratifikasi CEDAW ditindaklanjuti dengan UU No. 12 Tahun 2003 yang memberikan dorongan kepada perempuan untuk menjadi calon legislatif (caleg). Dampak dari undang-undang itu tidak hanya berkisar pada kesempatan bagi perempuan untuk menjadi anggota legislatif, namun turut menaikkan isu-isu gender secara luas. Menguatnya isu kesetaraan gender ini menggugah kesadaran dari Ibu Riniti yang saat itu menjadi anggota KPU Provinsi Bali. Ia mendorong representasi perempuan dalam caleg dan juga dalam struktur penyelenggara pemilu di tingkat kabupaten/kota. Untuk menuangkan ide-idenya untuk gagasan kesetaraan gender, ia dan rekan-rekannya kemudian mendirikan LSM Bali Sruti pada tahun 2004. 
Kapasitas dari aktor-aktor lokal untuk berinteraksi dengan norma kesetaraan gender sebagai norma global telah menciptakan suatu ruang sosial yang oleh Roudometof $(2005,129)$ sebut sebagai ruang sosial transnasionalisme. Ruang ini tidak merujuk pada orangorang yang bepergian secara fisik melintasi batas negara. Ruang sosial transnasional dibangun melalui interaksi transnasional yang dimediasi oleh berbagai sumber seperti internet, bahan cetak, televisi, konferensi internasional, berbagai jenis pariwisata internasional, serta perjanjian formal dan negosiasi yang sedang berlangsung dari beragam organisasi internasional dan kelompok non-pemerintah (Roudometof 2005, 129).

Ruang sosial yang diciptakan oleh aktivis-aktivis perempuan di Bali tidak mengikuti homogenisasi dalam penerapan norma global seperti dalam ungkapan globalis yaitu "berpikir global dan bertindak lokal" (Francois 2015, 64), namun menerapkan glokalisasi budaya lokal yang mengadaptasi dan mendefinisikan kembalisetiap produkbudayaglobalagar sesuai dengan kebutuhan, kepercayaan, dan kebiasaan khusus mereka (Khondker 2018, 96). Narasumber dalam penelitian ini menerapkan norma kesetaraan gender dengan menyesuaikan diri dengan bingkai nilai-nilai tradisi dibandingkan dengan menentangnya. Masyarakat Bali menganut garis patrilineal yang menempatkan laki-laki sebagai penerus garis keluarga. Akibatnya, laki-laki memegang posisi yang menentukan dalam pengambilan keputusan dalam bidang agama dan adat. Hal ini dicirikan oleh kehadiran laki-laki sebagai perwakilan keluarga dalam rapat-rapat untuk urusan agama dan adat. Dalam menghadapi tradisi ini, Ibu Riniti memilih untuk tidak menabrak tradisi ini karena hanya akan menimbulkan konflik. Yang selama ini beliau lakukan adalah dengan menghadirkan aspirasi perempuan tanpa perlu hadir secara langsung dalam rapat adat. Misalnya dalam pengambilan keputusan mengenai upacara agama di pura, perempuan dapat melakukan bargaining karena perempuanlah yang mengerjakan dan memiliki pengetahuan tentang cara membuat sesajen. Meskipun perempuan tidak hadir dalam rapat adat atau agama, perempuan dapat memengaruhi hasil rapat agar tidak diskriminatif dan adil bagi semuanya, baik laki-laki maupun perempuan. 
Hal serupa dilakukan Ibu Sri Wigunawati yang mengintegrasikan norma global kesetaraan gender ke dalam bingkai pengetahuan lokal orang Bali yang beragama Hindu. Dalam memengaruhi masyarakat untuk menerima kesetaraan gender, beliau mengutip seloka dalam kitab Manawa Dharma Sastra yang menyatakan bahwa, "Di mana wanita dihormati di sanalah para Dewa senang dan melimpahkan anugerahnya. Di mana wanita tidak dihormati, tidak ada upacara suci apapun yang memberikan pahala mulia”.

Aktivis perempuan di Bali menyadari bahwa tidak mungkin untuk bisa mengubah norma adat Bali yang patriarki secara konfrontatif. Yang mereka lakukan adalah mengubah sebagian dari tradisi dengan menggunakan cara berpikir adat, terminologi adat, dan melalui institusi yang diakui oleh desa adat. Majelis Utama Desa Pakraman (MUDP) merupakan lembaga yang dibentuk oleh Pemerintah Daerah Bali melalui Peraturan Daerah, meskipun secara mendasar bukanlah lembaga adat yang tumbuh dari kebiasaan. Warga adat terkoneksi secara tidak langsung dengan MUDP yang sekarang bernama Majelis Desa Adat (MDA). Semua orang Bali dan yang tinggal di Bali adalah warga dari desa adat. Desa-desa adat di Bali menerima dengan baik Peraturan Daerah yang mengatur tentang keberadaan desa pakraman atau desa adat, dengan MUDP sebagai institusi yang menaungi desa-desa adat tersebut. Sehingga, mereka berpikir bahwa perubahan tradisi patriarki dapat dilakukan lewat keputusan MUDP.

Karena MUDP dibentuk oleh Peraturan Daerah, maka sebagian tata kelolanya mengikuti manajemen pemerintah modern. Jika dalam struktur desa adat, perempuan tidak bisa menjadi pengurus, maka dalam struktur MUDP, perempuan dapat menjadi pengurus. Di tahun 2014, MUDP mulai melibatkan perempuan di dalam kepengurusannya. Dengan menggunakan konsep power cube dari Gaventa $(2006,26)$, kehadiran mereka adalah bentuk dari invited space, yaitu pelibatan orang-orang yang berada di posisi marginal dalam suatu pengambilan keputusan. Dengan invited space yang dimiliki oleh pengurus perempuan MUDP, pada tahun 2010 mereka memperjuangkan agenda yang sebelumnya tidak pernah dibahas dalam pengambilan keputusan adat yaitu hak waris (kekayaan) bagi anak perempuan. Menurut tradisi di Bali, hak waris adalah milik dari anak laki-laki sebagai penerus keturunan, 
The Dynamics of International Norms Diffusion:

The Study of Women Activists in Bali

bukan milik anak perempuan.

Dalam suatu lokakarya untuk mempersiapkan Pasamuhan Agung (rapat besar) MUDP ketiga pada tahun 2010, isu hak waris untuk anak perempuan sempat menjadi topik yang dibicarakan. Seorang ahli hukum adat yaitu Sudantra $(2011,24)$ menawarkan gagasan yang dia sebut sebagai gagasan moderat, yaitu dengan menyatakan bahwa orang tua berhak memberikan harta gunakaya (harta dari hasil kerja orang tua) kepada anak (perempuan) yang telah kawin keluar dari keluarga mereka, sepanjang pemberian harta itu tidak merugikan ahli waris (laki-laki). Meskipun aktivis perempuan tidak ingin menunjukkan sikap menentang secara frontal (terhadap norma adat Bali), mereka berusaha untuk mendapat maximum gain ketika mereka memiliki ruang memengaruhi keputusan. Saat itu, aktivis perempuan meminta sikap yang lebih tegas dibandingkan dengan yang disampaikan oleh Sudantra. Mereka tidak sependapat dengan kata supaya "orang tua berhak memberikan" harta warisan pada anak perempuan, namun mendorong supaya "anak yang telah kawin" (anak perempuan) berhak atas harta warisan orang tua (Sudantra 2011, 24).

Perjuangan aktivis perempuan di dalam MUDP yang didukung oleh sejumlah tokoh laki-laki yang mendukung kesetaraan gender telah menghasilkan dua keputusan penting dalam rapat besar MUDP di tahun 2010. Pertama, hak anak perempuan untuk mendapatkan harta warisan dari orang tuanya. Kedua, seorang ibu dapat mengasuh anaknya, jika terjadi perceraian. Dalam hukum adat Bali, anak adalah hak dari purusa (ayah) yang berarti bahwa hak asuh dimiliki oleh pihak ayah. Keputusan MUDP tersebut memberi pandangan yang berbeda terhadap hukum adat Bali. Anak tetap menjadi hak dari ayah, namun pengasuhan anak tersebut dapat dilakukan oleh ibunya.

Ketika aktivis perempuan Bali membawa isu tentang hak waris bagi anak perempuan dan hak asuh anak bagi ibu, mereka menciptakan ruang sosial transnasional ke dalam MUDP. Disebut dengan transnasional karena gagasan tersebut bersumber dari keterlibatan aktivis perempuan tersebut dalam proses difusi norma internasional tentang kesetaraan gender. Aktivis perempuan yang dilibatkan menjadi pengurus MUDP dapat mengubah invited space tersebut menjadi created space, yaitu ruang yang diciptakan 
oleh aktor-aktor yang less powerful untuk mengimbangi penguasa yang dominan (Gaventa 2006, 27). Dalam ruang ini, aktor-aktor sosial menolak ruang hegemonik dan menciptakan ruang untuk mereka (Soja 1996). Aktivis perempuan yang ada dalam MUDP berhasil mendorong MUDP untuk menghasilkan keputusan yang memberi penguatan pada perempuan Bali yang berada pada posisi yang marginal dibandingkan dengan laki-laki Bali.

Integrasi antara lokal dan bingkai globalisasi tidak selalu berjalan dengan mulus. Seperti yang dikatakan oleh Roudometof (2005), pakar glokalisasi kurang menaruh perhatian pada dimensi kekuasaan terutama memperhitungkan adalah ketegangan dan politik konfrontatif. Ada kalanya aktivis perempuan menghadapi situasi atau potensi situasi yang konfrontatif. Sebagai "entrepreneur" norma, aktivis perempuan di Bali menghadapi norma-norma lain yang telah embedded (melekat) dalam kehidupan masyarakat. Sebelum datangnya norma baru, sudah ada norma-norma lain yang mengisi ruang dan waktu dalam kehidupan masyarakat. Norma kesetaraan gender yang diturunkan dari CEDAW harus berkompetisi dengan norma dan persepsi kepentingan lainnya. Usaha untuk mempromosikan suatu norma baru berhadapan dengan standar "kepantasan" yang didefinisikan oleh norma-norma sebelumnya (Finnemore dan Sikkink 1998, 897).

Ibu Budawati menceritakan pengalamannya tentang penolakan dari laki-laki di suatu desa di Bali ketika beliau mensosialisasikan norma anti-kekerasan terhadap perempuan. Lembaganya dianggap sebagai lembaga yang radikal dalam menentang kekerasan terhadap perempuan. Akibatnya, sejumlah laki-laki menolak untuk diajak berdiskusi karena khawatir istri mereka mendapatkan pengaruh yang mereka anggap buruk dari aktivis perempuan. Walaupun pada awalnya mendapatkan resistensi, Ibu Budawati tetap menganggap bahwa dirinya perlu melakukan pendekatan kepada laki-laki untuk mengatasi isu kekerasan terhadap perempuan karena laki-lakilah yang menjadi pelakunya.

Ibu Budawati dengan lembaganya Bali Women Crisis Center (BWCC), kemudian menggunakan pendekatan ekonomi kreatif untuk mendapatkan penerimaan, terutama dari pihak suami. BWCC melakukan pelatihan pada para perempuan untuk 
The Dynamics of International Norms Diffusion:

The Study of Women Activists in Bali

berbagai kegiatan ekonomi misalnya membuat jepit rambut, dupa harum, dan pemberian bantuan bibit ternak. Kegiatan seperti ini menarik bagi perempuan dan juga membuat suaminya menerima kehadiran BWCC. Para suami kemudian menyatakan, "Oh dapat manfaat istri saya di BWCC". Dukungan dari suami dalam menerima BWCC memudahkan lembaga ini untuk berbicara tentang kekerasan terhadap perempuan dan kesetaraan gender secara umum. Beliau memilih untuk menggunakan pendekatan secara halus dibandingkan dengan cara yang konfrontatif.

Aktivis perempuan di Bali berusaha untuk menghindari hubungan yang konfrontatif. Dalam mendifusikan norma gender, penggunaan istilah gender ternyata menimbulkan resistensi. Menurut Ibu Anggreni, istilah gender menimbulkan kesan budaya Barat dan dianggap sebagai bentuk penjajahan terutama oleh pihak laki-laki. Hal serupa dinyatakan oleh Ibu Riniti. Beliau melihat resistensi pada istilah gender terjadi karena istilah itu mengandung makna konfrontatif. Ketika mendengar istilah gender, laki-laki secara umum melihatnya sebagai wacana yang menyalahkan dirinya. Para aktivis perempuan di Bali menyesuaikan diri dengan tampilan istilah dan memilih untuk tidak menggunakan istilah gender ketika berkomunikasi dengan khalayak luas.

\section{Jaringan Advokasi Internasional dalam Lingkup Mikro}

Ratifikasi CEDAW oleh negara tidak menjamin bahwa norma kesetaraan gender akan tersebar dalam ruang publik di ranah domestik. Difusi norma internasional HAM secara krusial tergantung pada keberlanjutan dari jaringan aktor domestik dan aktor transnasional (Risse 2017, 119-120). Jaringan advokasi transnasional mencakup aktor-aktor relevan yang bekerja secara internasional pada suatu isu, yang memiliki ikatan pada nilai-nilai dan wacana bersama, serta pertukaran informasi dan pelayanan (Keck dan Sikkink 1998, 2). Keberadaan dari jaringan-jaringan advokasi transnasional memberikan sumber daya bagi LSM-LSM di Bali yang bergerak dalam isu perempuan terutama dalam hal dukungan donor. Seperti yang dituturkan oleh Ibu Anggreni (yang saat itu menjadi pengacara di LBH Bali), peran dari lembaga donor internasional sangat penting dalam program LBH Bali dalam 
penanganan isu kekerasan terhadap perempuan. Hal senada juga dinyatakan oleh Ibu Riniti, bahwa funding dari berbagai donor di luar negeri sangat membantu dalam menggerakkan lembaganya, Bali Sruti menjadi cepat dalam menggerakkan sumber daya manusia.

Aktor-aktor dalam jaringan membawa gagasan, norma, dan wacana baru dalam formulasi kebijakan. Jaringan ini berfungsi sebagai sumber informasi dan testimoni (Keck dan Sikkink 1998, 2). Dalam gerakan aktivis perempuan di Bali, keterlibatan mereka dalam jaringan advokasi internasional tidak hanya memungkinkan mereka untuk mendapatkan informasi tentang perjuangan gender dari berbagai negara, namun mereka juga dapat membuat isu mereka tersampaikan. Mereka juga ingin agar pendekatan mereka dari segi kebudayaan, mendapatkan dukungan dari jaringan internasional tersebut. Seperti yang dinyatakan oleh Keck dan Sikkink (1998, 2), jaringan advokasi transnasional adalah struktur komunikatif. Untuk memengaruhi wacana, prosedur, dan kebijakan, para aktivis dapat terlibat dan menjadi bagian dari komunitas kebijakan yang menawarkan berbagai perspektif.

Interaksi internasional tersebut juga menghasilkan jaringan yang bertumbuh. Interaksi Ibu Riniti dengan rekan-rekannya sesama aktivis perempuan dari berbagai negara, memungkinkannya untuk bertemu dengan mitra baru yang dapat memberikan dukungan sumber daya, seperti lembaga World Justice Project. Lembaga ini memberikan dukungan pendanaan kepada LSM Bali Sruti untuk program sosialisasi hak waris bagi perempuan sesuai dengan hasil keputusan MUDP pada tahun 2010. Dalam hubungan dengan donor, Bali Sruti berperan sebagai implementing partner. Menurut Ibu Riniti, evaluasi dampak dari program tidak dapat ditentukan dalam jangka pendek. Kesinambungan dari gagasan hak waris perempuan ditentukan oleh penerimaan gagasan ini oleh kelompok pemuda. Ketika mereka berkeluarga dan memiliki anak perempuan, pada saat itulah difusi norma kesetaraan gender dalam hak waris dapat terlaksana dan berlanjut.

Pembentukan jaringan advokasi internasional bekerja seperti magnet, menarik pihak-pihak yang terlibat untuk membuka diri pada kemitraan dengan kelompok lain di luar negeri yang memiliki acuan norma yang sama. Ketika Ibu Budawati menulis 
The Dynamics of International Norms Diffusion: The Study of Women Activists in Bali

tentang kekerasan terhadap perempuan di Bali di sebuah majalah berbahasa Inggris, yaitu Bali Travel News, beliau tidak hanya sedang membuka informasi yang selama ini jarang diketahui orang, namun secara bersamaan, beliau juga membuka diri untuk bekerja sama dengan pihak-pihak yang ingin menangani kekerasan terhadap perempuan. Tulisan tersebut mengantarkan beliau pada perkenalan dengan aktivis perempuan di Australia, manajer bagian psikologi dari Barwon CASA. Aktivis Barwon CASA saat itu sedang duduk-duduk santai di Pantai Kuta dan menemukan majalah Bali Travel News yang memuat tulisan Ibu Budawati tentang kekerasan perempuan di Bali. Aktivis tersebut kemudian pulang ke Australia dan dari negaranya ia menelepon Ibu Budawati untuk berkenalan.

Setelah perkenalan tersebut, Ibu Budawati tidak menyangka bahwa aktivis perempuan Australia tersebut benar-benar datang menemuinya bahkan tanpa janji untuk bertemu. Saat pertama kali ia menemui Ibu Budawati, ia langsung menangis sambil membawa tulisan Ibu Budawati di Majalah Bali Travel News. "Is that you?" katanya untuk mengonfirmasi bahwa ia telah bertemu dengan Ibu Budawati. Aktivis Australia tersebut memiliki kesan dan kecintaan pada Bali. Artikel dari Ibu Budawati tersebut membuatnya terkejut dan prihatin tentang kekerasan terhadap perempuan dan anak di Bali yang tidak pernah dirinya kira sebelumnya. Peristiwa itu menunjukkan bahwa pembentukan kemitraan jaringan advokasi internasional, khususnya dalam isu perempuan, tidak hanya berkaitan dengan persamaan platform gerakan kesetaraan gender, namun juga perkara relasi emosi antara subjek dengan orangorang atau tempat tertentu yang dalam hal ini adalah relasi emosi antara aktivis Australia tersebut dengan Bali.

Kerja dari jaringan advokasi internasional didasari oleh intersubjektivitas dalam perumusan makna. Seperti yang dinyatakan Riyanto (2018, 225), gagasan intersubjektivitas menunjuk pada pandangan yang membuat urusan subjek mengemuka. Kerangka dasar intersubjektif adalah bahwa setiap manusia yang berelasi adalah pribadi yang memiliki pengalaman kontributif terhadap komunitasnya. Intersubjektif mengandaikan suatu bentuk kedalaman relasional. Relasi yang intersubjektif berlangsung secara sepadan, sederajat, dan semartabat. Paparan Ibu Budawati tentang kerja pendampingan yang beliau lakukan, 
menghasilkan rasa hormat pada diri aktivis Australia tersebut dan menumbuhkan komitmennya untuk memberikan asistensi.

Komitmen tersebut mewujud dalam bentuk penggalangan isu dan mobilisasi sumber daya di negara asing (Australia) untuk mendukung penanganan isu di wilayah domestik yang bersangkutan (Bali). Ketika aktivis tersebut kembali ke Australia, ia melakukan penggalangan dana di tingkat lokal agar bisa mendatangkan Ibu Budawati ke Australia untuk studi banding tentang penanganan kekerasan terhadap perempuan. Dia menggalang dana dengan acara menonton film bersama dan mengumpulkan donasi dari para peserta. Kegiatan tersebut sekaligus berfungsi untuk mendapatkan audiens yang lebih luas di Australia karena ia menjelaskan peruntukan dari penggalangan donasi tersebut kepada para donatur. Kunjungan Ibu Budawati kemudian menjadi awal dari bentuk kemitraan antara Barwon CASA di Australia dengan BWCC di Bali.

Dalam jaringan advokasi internasional, kemitraan antara Barwon CASA dengan BWCC terjadi dengan pola hubungan antara Barwon CASA sebagai norms promotor dan BWCC sebagai norms translator. Orang-orang dari Barwon CASA tiap tahun datang ke Bali untuk membawa pesan-pesan kesetaraan gender di komunitas-komunitas dampingan BWCC. Gagasan-gagasan dari Barwon CASA yang dirasa penting oleh BWCC, kemudian diterjemahkan dalam bentuk program kegiatan. Barwon CASA juga berperan sebagai konsultan atas kegiatan-kegiatan BWCC yang mencakup pendampingan kasus hukum kekerasan terhadap perempuan; menjadi trainer dalam pelatihan para legal di Bali; membantu membangun strategi BWCC untuk masa yang akan datang; dan penguatan SDM secara internal. Di samping itu, lembaga juga berperan sebagai patronasi (penyokong) dengan memberikan dukungan dana untuk program pendampingan dan sosialisasi. Menurut Ibu Budawati, meskipun jumlah dananya tidak besar, beliau menilai bahwa secara keseluruhan kemitraan dengan Barwon CASA memberikan manfaat yang besar bagi kegiatan BWCC. 
The Dynamics of International Norms Diffusion: The Study of Women Activists in Bali

\section{Transnational Engagement dan Adopsi Gagasan}

Engagement aktor gerakan kesetaraan gender dengan ranah internasional memungkinkan aktor untuk mengadopsi gagasan baru. Saat Ibu Budawati berinteraksi dengan rekan-rekannya di Barwon CASA, mitranya dari Australia tersebut memberikan masukan bahwa tidak selamanya ia bisa melakukan sosialisasi dari satu tempat ke tempat lainnya di sejumlah kabupaten di Bali. Dirinya tidak akan bisa melakukannya secara terus menerus karena saat berusia senja, gerakan fisik akan terbatas. Selanjutnya, mitra Australia tersebut menyatakan bahwa saat di usia senja, polanya harus diubah dengan cara, "Kitalah yang mengundang orang lain dan merekalah yang mendatangi kita agar pengetahuan dan pengalaman kita dapat diteruskan kepada orang lain”. Untuk mempersiapkan hal itu, diperlukan sebuah tempat yang memungkinkan adanya pertemuan seperti community centre. Saat itu, Ibu Budawati menilai bawha ide tersebut belum feasible karena rumahnya di Desa Penatahan terlalu jauh untuk dijangkau dari kota-kota di Bali.

Ibu Budawati kembali mendapat pertukaran gagasan di ranah transnasional pada tahun 2018, ketika ia terpilih sebagai peserta dalam program International Visitor Leadership Program di Amerika Serikat. Program ini difasilitasi oleh Kementerian Luar Negeri Amerika Serikat. Dalam program yang berlangsung selama sebulan itu, ia mendapat kesempatan untuk berkunjung ke berbagai organisasi di Amerika Serikat untuk mempelajari strategi dan kerja-kerja berjejaring dalam mendampingi kasus kekerasan termasuk sekolah paralegal.

Dalam kunjungan internasionalnya, identitas Ibu Budawati sebagai pejuang kesetaraan gender bertemu dengan situasi baru. Dengan mengikuti cara berpikir teori konstruktivis, aktor bertindak mengikuti aturan atau norma yang menghubungkan antara identitas dengan situasi tertentu (Risse 2000, 4). Di Amerika Serikat, Ibu Budawati terkesan dengan sekolah paralegal yang para pesertanya dapat membantu penanganan kasus kekerasan terhadap perempuan dan anak. Dalam hal ini, telah terjadi engagement antara identitasnya dengan situasi yang baru yang kemudian menghasilkan pemahaman baru tentang peran dari paralegal dalam jaringan penanganan kekerasan terhadap 
perempuan.

Exposure dengan interaksi internasional juga dialami oleh Ibu Sri yang mendapatkan kesempatan untuk melakukan studi banding ke Amerika melalui program American Council for Young Political Leaders (ACYPL) pada tahun 2008. Beliau bertemu dengan sejumlah aktivis perempuan di Amerika yang membantu politisi perempuan berkompetisi untuk jabatan-jabatan politik seperti anggota Kongres maupun Presiden. Dengan contohcontoh yang diamati di sana, beliau menjadi semakin yakin dengan pandangan bahwa perempuan yang berada dalam posisi pengambilan keputusan, akan dapat menyelesaikan banyak isuisu yang dihadapi perempuan. Beliau melihat upaya dari aktivis dan politisi perempuan memperjuangkan legalitas aborsi bagi perempuan yang berposisi sebagai korban.

Kunjungannya ke tiga negara bagian di Amerika menghadirkan makna kolektif (makna dikonstruksikan bersama dengan orang lainnya). Teori konstruktivis dalam hubungan internasional menekankan bahwa norma-norma dan pemahaman kolektif mengonstitusi identitas-identitas sosial dari aktor dan juga mendefinisikan "rule of the game" dasar yang di dalamnya aktor menemukan dirinya dalam interaksinya (Risse 2000, 4-5). Pemahaman kolektif yang ia dapatkan dari pengalaman internasionalnya, mengonstitusi identitas sosial dalam kesehariannya sebagai politisi perempuan. Identitas sosialnya tampak pada pernyataannya bahwa "perempuan harus aktif terlibat politik untuk mengatasi isu-isu perempuan, karena hanya perempuan yang tahu persis masalahnya". Sepulang dari Amerika, identitas sosialnya juga tampak adalah cara pandangnya tentang demokrasi sebagai jalan keluar dari semua isu publik termasuk isu kesetaraan gender. Baginya, jika demokrasi sudah kuat, maka semua suara publik termasuk dari kelompok marginal akan mendapatkan ruang dalam pengambilan keputusan. Pandangan ini dan contoh-contoh keberhasilannya di Amerika sering ia utarakan dalam berbagai forum pertemuan untuk mendorong kesadaran perempuan tentang politik.

Identitas sosial dari Ibu Sri menentukan dasar dari dirinya untuk bertindak dalam kesehariannya. Beliau meyakini bahwa keterlibatan dalam kebijakan publik adalah partisipasi sebagai 
The Dynamics of International Norms Diffusion:

The Study of Women Activists in Bali

warga negara yang baik. Walaupun belum berhasil dalam usaha untuk mencari pejabat politik dalam sejumlah kontestasi, beliau melihat perjuangan politisi perempuan juga dapat dilakukan dengan lobbying pada pembuat keputusan dan penyelenggara negara. Identitas sosial tersebut yang mendasarinya untuk tetap terlibat dalam politik selama lebih dari 24 tahun.

\section{Pertemuan Kesempatan Politik Dalam dan Luar Negeri}

Teori-teori tentang kerja dari difusi norma HAM internasional lebih memperhatikan pada tekanan yang dilakukan oleh jaringan advokasi internasional pada pemerintah di negara non-Barat yang dianggap melanggar norma HAM (Risse 2017; Keck dan Sikkink 1998). Mereka kurang memperhatikan kerja jaringan advokasi internasional di negara-negara yang pemerintahnya sudah terbuka terhadap difusi norma, seperti halnya Indonesia. Secara struktur, keberadaan dan program kerja dari Kementerian Pemberdayaan Perempuan dan Perlindungan Anak (KPPA) adalah kesempatan politik bagi kerja aktivisme kesetaraan gender. Ibu Budawati berhasil mengombinasikan kesempatan politik di tingkat domestik dan internasional.

Dalam literatur gerakan sosial, struktur kesempatan politik mengacu pada kondisi-kondisi dalam sistem politik yang baik memfasilitasi atau juga menghambat suatu tindakan kolektif (Tilly 1978, 115). Dalam gerakan sosial, struktur kesempatan politik mempengaruhi aktor untuk memobilisasi sumber daya, yang membantu terealisasinya suatu gagasan. Selepas dari kunjungan dari Amerika, Ibu Budawati sangat berkeinginan untuk mewujudkan ide yang pada awalnya merupakan saran dari mitranya dari Australia, yaitu membangun tempat yang bisa menjadi pusat belajar tentang kesetaraan gender, termasuk kegiatan sekolah paralegal yang terinspirasi dari pengalaman kunjungannya di Amerika. Tempat tersebut dibayangkan sebagai tempat serba guna yang juga mencakup kegiatan sosialisasi hukum, bedah kasus, peradilan semu, dan pemberdayaan ekonomi kreatif. Gagasan tersebut memungkinkan terealisasi dengan adanya kesempatan dari KPPA untuk pengembangan desa wisata berbasis perlindungan perempuan dan anak. 
Ibu Budawati bersama perempuan di Desa Penatahan memberdayakan potensi desanya berupa mata air panas, pemandangan sawah, jalur tracking dan aktivitas budaya keagamaan. Untuk tempat akomodasi, beliau dan kelompoknya membangun vila yang tidak menggunakan bahan beton sebagai wujud dari kesadaran lingkungan. Tempat akomodasi inilah yang dijadikan sebagai tempat sekolah paralegal dan pelatihanpelatihan gender lainnya, selain digunakan untuk akomodasi wisata yang dapat membantu perekonomian di desanya. Tempat akomodasi ini memberi nilai tambah dari segi pariwisata dengan menghadirkan suasana alam pegunungan dan budaya di desa yang otentik. Kegiatan sekolah paralegal kemudian memungkinkan untuk dapat terlaksana dengan adanya dukungan pendanaan dari Konsulat Jenderal Amerika Serikat. Sekolah paralegal tersebut diberi nama LBH Kubu Bali BWCC.

\section{Simpulan}

Difusi norma internasional kesetaraan gender tidak terjadi secara linear yang menetes dari ranah global menuju ranah domestik, seperti yang dinyatakan oleh Finnemore dan Sikkink. Meskipun negara telah meratifikasi CEDAW, internalisasi norma global kesetaraan gender di tingkat lokal melibatkan proses yang kompleks. Norma global tersebut menemukan hambatan untuk dapat diterima dalam masyarakat dengan budaya patriarki seperti halnya di Bali. Terdapat peran penting dari aktivis perempuan di Bali sebagai "entrepreneur" norma, yang mengemas dan mempromosikan norma kesetaraan gender agar mendapatkan penerimaan dan penerapan yang luas. Mereka berperan dalam proses glokalisasi dengan mencari celah masuk dan penyesuaian, agar norma global kesetaraan gender dalam masuk dalam ruang budaya masyarakat Bali. Mereka memilih pendekatan efektif dan perlahan serta menghindari cara-cara yang konfrontatif. Strategi yang mereka gunakan di antaranya adalah mendorong adanya keputusan MUDP untuk mengubah sebagian tradisi adat Bali yaitu dalam hal hak waris untuk anak perempuan dan hak asuh bagi perempuan jikalau terjadi perceraian. 
The Dynamics of International Norms Diffusion: The Study of Women Activists in Bali

Interaksi para aktivis kesetaraan gender dengan ruang transnasional berupa keterlibatan dalam jaringan advokasi internasional dan kunjungan studi banding ke luar negeri memperkuat identitas mereka sebagai aktivis perempuan dan memiliki tambahan wawasan, baik dalam wacana maupun strategi praktis. Interaksi tersebut juga berdampak pada penggunaan strategi yang telah berhasil di luar negeri untuk dibawa di tingkat lokal. Wacana demokrasi sebagai solusi masalah perempuan, seperti yang terjadi di Amerika, diterapkan di tingkat Bali untuk mengundang agar perempuan lebih aktif dalam politik. Gagasan sekolah paralegal yang dipelajari di Amerika juga diadopsi untuk memperkuat jaringan advokasi pada kekerasan terhadap perempuan pada khususnya dan kesetaraan gender pada umumnya.

Interaksi internasional juga telah memberikan kesempatan politik bagi gerakan perempuan di Bali berupa dukungan pendanaan dalam sosialisasi, pendidikan, dan pendampingan kasus kekerasan terhadap perempuan. Kebijakan negara berupa desa wisata ramah perempuan dan anak telah menjadi kesempatan politik yang telah digunakan dengan efektif untuk membentuk suatu tempat yang tidak hanya menjadi pusat pembelajaran gender, namun juga secara bersamaan meningkatkan taraf ekonomi perempuan kelompok sadar wisata. Difusi norma memiliki dampak yang berlanjut ketika aktor-aktor lokal yang efektif terjadi melalui glokalisasi yang titik pusatnya terletak pada agensi dan pilihan strategi gerakan dari aktivis perempuan.

\section{Referensi}

\section{Buku dan Bab dalam Buku}

Davies, Sara, et al., 2015. Disease Diplomacy: International Norms and Global Health Security. Bartimore, MD: Johns Hopkins University Press.

Francois, Emmanuel Jean, 2015. Building Global Education with A Local Perspective. New York: Palgrave Macmillan.

Keck, Margaret E., dan Kathryn Sikkink. 1998. Activists beyond Borders. Ithaca: Cornell University Press. 
Keohane, Robert O., dan Joseph S. Nye. 200o. "Governance in a Globalizing World.” dalam Robert O. Keohane (ed.), 2000. Power and Governance in a Partially Globalized World, 193-218. New York: Routledge.

Khondker, Habibul, 2018. "Glocalization", dalam Mark Juergensmeyer, et al. (eds.), 2018. The Oxford Handbook of Global Studies, Oxford: Oxford University Press.

McAdam, Doug, 1982. Political Process and the Development of Black Insurgency, 1930-1970. Chicago: University of Chicago Press.

Risse, Thomas, 2017. Domestic Politics and Norm Diffusion in International Relation: Ideas Do Not Float Freely. London and New York: Routledge.

Riyanto, Armada, 2018. Relasionalitas Filsafat Fondasi Interpretasi: Aku, Teks, Liyan, Fenomen. Yogyakarta: PT. Kanisius.

Robertson, Roland, 1992. Globalization: Social Theory and Global Culture. London: Sage.

Smith, David Woodruff, 2013. Husserl (2nd ed.). London and New York: Routledge.

Soja, Edward W., 1996. Third Space: Journeys to Los Angeles and Other Imagined Places. Cambridge: Blackwell Publishing.

Suryani, Luh Ketut, 2003. Perempuan Bali Kini. Denpasar: Bali Post.

Tilly, Charles, 1978. From Mobilization to Revolution. Reading, MA: Addison-Wesley.

Wylie, Gillian, 2016. The International Politics of Human Trafficking. Basingstoke, Hampshire: Palgrave Macmillan. 
The Dynamics of International Norms Diffusion:

The Study of Women Activists in Bali

\section{Jurnal}

Acosta, Mariola, et al., 2019. "Discursive Translations of Gender Mainstreaming Norms: The Case of Agricultural and Climate Change Policies in Uganda", Women's Studies International Forum, 74: 9-19.

Bloomfield, Alan, 2016. "Norm Antipreneurs and Theorising Resistance to Normative Change", Review of International Studies, 42 (2): 310-33.

Finnemore, Martha, dan Kathryn Sikkink, 1998. "International Norm Dynamics and Political Change", International Organization, 52 (4): 887-917.

Gaventa, John. 2006. "Finding the Spaces for Change: A Power Analysis", IDS Bulletin 37 (6): 23-33.

Gelgel, Ni Made Ras Amanda, dan Kadek Dwita Apriani. 2019. "Rendahnya Keterpilihan Perempuan Pada Pemilu 2019 Di Bali”, Jurnal Kajian Bali 09 (02): 263-87.

Hughes, Mellanie M., et al., 2015. "Transnational Women's Activism and the Global Diffusion of Gender Quotas", International Studies Quarterly, 59: 357-372.

Iommi, Lucrecia García, 2020. "Norm Internalisation Revisited: Norm Contestation and the Life of Norms at the Extreme of the Norm Cascade", Global Constitutionalism 9 (1): 76-116.

Jessica, Kim. 2020. "The Diffusion of International Women's Rights Norms to Individual Attitudes", Sociology of Development, 6: 459-92.

Jose, Betcy, 2016. "Bin Laden's Targeted Killing and Emerging Norms", Critical Studies on Terrorism, 10 (1): 44-66.

Risse, Thomas, 2000. "Let's Argue! Communicative Action in World Politics", International Organization, 54 (1): 1-39.

Roudometof, Victor, 2005. "Transnationalism, Cosmopolitanism and Glocalization", Current Sociology, 53 (1): 113-135.

Sørensen, Ninna Niberg, 2018. "Diffusing Gender Equality Norms in the Midst of a Feminicide Pandemic: The Case of AMEXCID 
and Decentralized Mexican South-South Cooperation", Progress in Development Studies 18 (2): 95-109.

Swingel, Sussane, 2012. "How Do Norms Travel? Theorizing International Women's Rights in Transnational Perspective", International Studies Quarterly, 56: 115-129.

\section{Artikel Daring}

Gerintya, Scholastica. 2019. "Bagaimana Keterwakilan Perempuan Dan Anak Muda Di DPR 2019-2024?” Tirto.id, 19 Oktober 2019. https://tirto.id/bagaimana-keterwakilan-perempuandan-anak-muda-di-dpr-2019-2024-ejwt [diakses pada 1 Agustus 2021].

Tribun Bali, 2020. "Terdata 408 Kasus, Kasus KDRT Di Bali Meningkat Dua Kali Lipat.” Tribun Bali, 28 Januari [daring]. dalam https://bali.tribunnews.com/2020/01/28/terdata408-kasus-kasus-kdrt-di-bali-meningkat-dua-kali-lipat [diakses pada 1 Agustus 2021].

\section{Wawancara}

Anggreni, Luh Putu, 2021. "Wawancara dengan Pengurus LBH APIK Bali”, diwawancarai oleh Ngakan Nyoman Giriyasa, 22 Juni 2021.

Budawati, Ni Nengah, 2021. "Wawancara dengan Pendiri LBH APIK dan Pendiri serta Direktur Bali Women Crisis Centre", diwawancari oleh Ngakan Nyoman Giriyasa, 14 Juni 2021.

Rahayu, Luh Riniti, 2021. "Wawancara dengan Pendiri dan Ketua Yayasan Bali Sruti”, diwawancari oleh I Made Anom Wiranata, 18 Juni 2021.

Wigunawati, Dewa Ayu Sri, 2021. "Wawancara dengan Politisi Partai Golkar Bali dan Ketua KPPI Provinsi Bali”, diwawancarai oleh Putu Jianing Chiandewi dan Putu Miastiti Negari, 9 Juni 2021. 
The Dynamics of International Norms Diffusion:

The Study of Women Activists in Bali

\section{Lainnya}

Congressional Research Service, 2015. "The U.N. Convention on the Elimination of All Forms of Discrimination Against Women (CEDAW): Issues in the U.S. Ratification Debate."

Sudantra, I Ketut, 2011. “Agar Luh Tak Sekadar Peluh.” Bali Sruti, 2011. 